\title{
Germination and morphophysiology of passion fruit seedlings under salt water irrigation ${ }^{1}$
}

\author{
Jailma Ribeiro de Andrade ${ }^{2}$, Aldair de Sousa Medeiros², \\ Sebastião de Oliveira Maia Júnior ${ }^{2}$, Leila de Paula Rezende ${ }^{2}$, João Correia de Araújo Neto ${ }^{2}$
}

\begin{abstract}
The use of salt water in irrigation can reduce the growth and yield of agricultural crops. This study aimed to assess the germination, emergence, physiology and growth of passion fruit seedlings of two varieties under salt water irrigation. The study was conducted in two stages: the first carried out in a laboratory and the second in a greenhouse, using a randomized block design, in a $2 \times 4$ factorial scheme, corresponding to two passion fruit varieties (BRS RC and BRS GA1) and four levels of irrigation water electrical conductivity $\left(0.2 \mathrm{dS} \mathrm{m}^{-1}\right.$, $2.2 \mathrm{dS} \mathrm{m}^{-1}, 4.2 \mathrm{dS} \mathrm{m}^{-1}$ and $6.2 \mathrm{dS} \mathrm{m}^{-1}$ ), with four replications. The BRS GA1 variety exhibited the highest germination index and rate, in the germination stage, despite being more sensitive to salinity than the BRS RC. There was no damage to the photosynthetic apparatus in the BRS GA1 seedlings during growth, as demonstrated by the higher leaf biomass, when compared to the BRS RC variety.
\end{abstract}

KEYWORDS: Passiflora edulis; vegetative growth; salinity.

\section{INTRODUCTION}

Passion fruit (Passiflora edulis) cultivation is important in the Brazilian agribusiness, largely due to its commercialization in the form of juice concentrate (Oliveira et al. 2015). Brazil is the world's largest producer of the fruit, but its yield is still considered low: approximately 14.1 tha year $^{-1}$ (IBGE 2016). This results from inadequate crop management practices, phytosanitary problems and, primarily, poor quality irrigation water, in some northeastern regions (Aguiar et al. 2015).

The soil and climate conditions in Northeast Brazil favor the passion fruit cultivation (Lima et al. 2016a). However, the high salt levels present in irrigation water significantly reduce the crop

\section{RESUMO}

Germinação e morfofisiologia de plântulas de maracujazeiro sob irrigação com água salina

O uso de água salina na irrigação provoca redução no crescimento e produtividade de culturas agrícolas. Objetivou-se avaliar a germinação, emergência, fisiologia e crescimento de mudas de duas variedades de maracujazeiro, sob irrigação com água salina. A pesquisa foi conduzida em duas etapas: a primeira em laboratório e a segunda em casa-de-vegetação, sob delineamento em blocos ao acaso, em esquema fatorial $2 \times 4$, correspondendo a duas variedades de maracujazeiro (BRS RC e BRS GA1) e quatro níveis de condutividade elétrica da água de irrigação $\left(0,2 \mathrm{dS} \mathrm{m}^{-1} ; 2,2 \mathrm{dS} \mathrm{m}^{-1} ; 4,2 \mathrm{dS} \mathrm{m}^{-1}\right.$; e $6,2 \mathrm{dS} \mathrm{m}^{-1}$ ), com quatro repetições. A variedade BRS GA1, apesar de ser mais sensível ao nível de salinidade do que a BRS RC, na fase de germinação, apresenta maior índice e porcentagem de germinação. Durante o crescimento das mudas, a variedade BRS GA1 não sofre danos no aparelho fotossintético, como evidenciado pela maior biomassa das folhas que na BRS RC.

PALAVRAS-CHAVE: Passiflora edulis; crescimento vegetativo; salinidade.

expansion to semiarid regions (Nobre et al. 2013, Lima et al. 2016b), characterized by an uneven spatial and temporal rainfall distribution. As such, irrigation is one of the main technologies used in these areas to safeguard the agricultural production (Souza et al. 2016); however, the use of water with a high salt content may compromise seedling germination and growth, depending on the genotype and salt levels involved (Sá et al. 2013 and 2017).

Plants grown in a saline medium exhibit changes in growth and a lower yield, because the high salt levels in the soil solution alter the osmotic potential and ion toxicity, in addition to cause a nutrient imbalance (Sá et al. 2013). This compromises the physiological and biochemical performance, hampering the plant-water relations 
and the absorption of essential nutrients (Freire et al. 2014, Souza et al. 2016).

The effects of salt water irrigation on the production of fruit seedlings have already been investigated in papaya (Sá et al. 2013), guava (Souza et al. 2016), cashew apple (Silva et al. 2009, Sousa et al. 2011) and passion fruit (Sousa et al. 2008, Moura et al. 2017). Nevertheless, the magnitude of the effect of salt water on plants depends on other factors, such as the species, genotype, type of salt, stress intensity and duration, irrigation management and crop development stage, requiring the use of tolerant material, when applying salt water to agricultural crops (Lima et al. 2016b).

Passion fruit is highly sensitive to salinity (Dias et al. 2011), which affects the plant photosynthetic apparatus. This effect can be interpreted by the maximum quantum efficiency of the photosystem II, through the $\mathrm{Fv} / \mathrm{Fm}$ ratio, or by damage to photosynthetic pigments, assessed via the chlorophyll content (SPAD) index (Freire et al. 2014), thus decreasing seedling growth and dry weight yield (Bezerra et al. 2016, Cavalcante et al. 2018).

Thus, it is vital that studies be conducted during the seedling formation phase (Sá et al. 2013), whereby quality seedlings with a greater vigor and root/shoot balance favor the adaptation to the cultivation conditions (Lima et al. 2016a). In this context, this study aimed to assess the germination, emergence, physiology and growth of seedlings of two passion fruit varieties, under salt water irrigation.

\section{MATERIAL AND METHODS}

The study was carried out in two stages, from August to November 2015, at the Universidade Federal of Alagoas, in Rio Largo, Alagoas state, Brazil (09'28'02'S, 35\%49'43' W and altitude of $127 \mathrm{~m}$ ). The first stage (germination) was conducted in a laboratory and the second (seedling growth and physiology) in a greenhouse.

Commercial seeds of the BRS Rubi do Cerrado (BRS RC) and BRS Gigante Amarelo (BRS GA1) passion fruit varieties were provided by the Embrapa Cerrado, with purity and germination of $99 \%$ and $90 \%$, respectively. For the experiment conducted in the laboratory, the seeds were submersed in different sodium chloride solutions $(\mathrm{NaCl})$. The table proposed by Richards (1954) was followed to obtain the solutions, whereby salt was diluted in distilled water, to achieve irrigation water electrical conductivities (ECw) of $0.2 \mathrm{dS} \mathrm{m}^{-1}, 2.2 \mathrm{dS} \mathrm{m}^{-1}, 4.2 \mathrm{dS} \mathrm{m}^{-1}$ and $6.2 \mathrm{dS} \mathrm{m}^{-1}$.

A completely randomized design was used, with treatments arranged in a $2 \times 4$ factorial scheme (passion fruit varieties $\mathrm{x}$ water electrical conductivity) and four replications. Twenty-five seeds were distributed over germitest paper and wet with saline solutions corresponding to the treatments at 2.5 times the weight of the dry paper (Brasil 2009). The obtained rolls were stored in a BOD incubator, at an alternating temperature of $25-30^{\circ} \mathrm{C}$. The germination index and rate were assessed (Gorla \& Perez 1977), in addition to seedling and root dry weight.

At the end of the experiment, the data were submitted to analysis of variance, whereby the treatments corresponding to the conductivity of irrigation water were analyzed by polynomial regression, using the Sisvar 5.6 statistical software (Ferreira 2014).

The second experiment was performed in the seedling stage, using a randomized block design, in a $2 \times 4$ factorial scheme, in which the treatments consisted of two passion fruit varieties (BRS RC and BRS GA1) and four levels of water electrical conductivity $\left(0.2 \mathrm{dS} \mathrm{m}^{-1}, 2.2 \mathrm{dS} \mathrm{m}^{-1}, 4.2 \mathrm{dS} \mathrm{m}^{-1}\right.$ and $6.2 \mathrm{dS} \mathrm{m}^{-1}$ ), with 4 replications and 2 plants per plot. The water electrical conductivity levels were prepared in accordance with the first experiment. The irrigation with salt water was performed as needed, by drainage lysimetry, where the volume of water applied was obtained based on the difference between the volume applied and drained in the previous irrigation (Silva et al. 2017).

The seedlings were grown in $300 \mathrm{~mL}$ polyethylene tubes, washed with sodium hypochlorite and filled with a commercial Bioplant ${ }^{\mathbb{R}}$ substrate (pinus bark, humus and vermiculite; $\mathrm{pH} 6.0 \pm 1.0$ ). Irrigation was performed daily to ensure that the substrate was always close to the field capacity. One passion fruit seed was planted in each tube. The irrigation with salt water, corresponding to the treatments, was initiated at 30 days after planting (DAP). The following variables were assessed at 50 days after the application of the saline treatments: plant height, stem diameter, number of leaves, leaf area, chlorophyll content index (SPAD), maximum quantum efficiency of PSII (Fv/Fm), and leaf, stem and root dry weight.

Plant height was measured in centimeters, from the base to the insertion point of the youngest leaf, 
using a measuring tape, and stem diameter at the base of the plant, with a digital pachymeter. The SPAD index was determined using a SPAD-502 portable chlorophyll meter, taking five readings on the third fully expanded leaf to obtain an average per leaf.

The maximum quantum efficiency of PSII $(\mathrm{Fv} / \mathrm{Fm})$ was assessed using a portable chlorophyll fluorometer (PAM 2500, WALZ) (Maxwell \& Johnson 2000). Measurements were taken between 11 a.m. and 12 p.m. on the same leaves used to determine the SPAD index, which were pre-adapted to the dark, for $30 \mathrm{~min}$.

Leaf area was measured using an LI-3100C area meter (LI-COR, USA). Next, the plants were dried in a forced air oven at $65{ }^{\circ} \mathrm{C}$, until constant weight, when the leaf, stem and root dry weight were determined.

The data were submitted to analysis of variance, whereby the treatments corresponding to the conductivity of irrigation water were analyzed by polynomial regression, using the Sisvar 5.6 statistical software (Ferreira 2014).

\section{RESULTS AND DISCUSSION}

According to the analysis of variance summary (Table 1), the salinity of the irrigation water significantly affected $(\mathrm{p}<0.05)$ the germination speed index, germination rate and seedling dry weight. With respect to the passion fruit varieties, a significant difference $(p<0.05)$ was observed for the germination speed index, germination rate and root dry weight. For the irrigation water salinity $\mathrm{x}$ variety interaction, there was a significant effect for all the variables, except for root dry weight.

Table 1. Analysis of variance summary for the germination speed index (GSI), germination rate $(\mathrm{G} \%)$, seedling dry weight (DWs) and root dry weight (DWr) of passion fruit varieties submitted to irrigation water electrical conductivities.

\begin{tabular}{lcccc}
\hline \multirow{2}{*}{ Sources of variation } & \multicolumn{4}{c}{ F-test } \\
\cline { 2 - 5 } & GSI & \multicolumn{1}{c}{ G\% } & DWs & DWr \\
\hline Salinity (S) & $14.41^{*}$ & $5.02^{*}$ & $3.56^{*}$ & $1.64^{\mathrm{ns}}$ \\
Linear regression & $25.68^{*}$ & $1.36^{\mathrm{ns}}$ & $0.03^{\mathrm{ns}}$ & $0.27^{\mathrm{ns}}$ \\
Quadratic regression & $11.80^{*}$ & $10.27^{*}$ & $5.29^{*}$ & $2.31^{\mathrm{ns}}$ \\
Variety (V) & $36.69^{*}$ & $15.32^{*}$ & $0.04^{\mathrm{ns}}$ & $10.77^{*}$ \\
S x V & $3.73^{*}$ & $3.76^{*}$ & $5.61^{*}$ & $1.95^{\mathrm{ns}}$ \\
\hline $\mathrm{CV}(\%)$ & 13.30 & 6.50 & 18.70 & 21.30 \\
\hline
\end{tabular}

${ }_{\mathrm{ns}}$ and $*$ : not significant and significant, respectively, according to the F-test at $5 \%$.
An increase in the irrigation water salinity to $1.26 \mathrm{dS} \mathrm{m}^{-1}$ raised the germination speed index of BRS GA1 seeds, reaching an estimated maximum value of 26.2, at an estimated water electrical conductivity of $1.26 \mathrm{dS} \mathrm{m}^{-1}$, and then declining to $6.2 \mathrm{dS} \mathrm{m}^{-1}$. In the BRS RC variety, seeds achieved a germination speed index of 19.1 at a water electrical conductivity of $2.29 \mathrm{dS} \mathrm{m}^{-1}$, declining thereafter and equaling the BRS GA1 at $6.2 \mathrm{dS} \mathrm{m}^{-1}$ (Figure 1A). Similarly, germination rates were higher in the BRS GA1 variety, reaching a maximum of $93 \%$ at $1.83 \mathrm{dS} \mathrm{m}^{-1}$ and decreasing as the salt level increased, whereas the peak germination in the BRS RC seeds was $85.4 \%$ at $2.72 \mathrm{dS} \mathrm{m}^{-1}$, not differing from the BRS GA1 at $6.2 \mathrm{dS} \mathrm{m}^{-1}$ (Figure 1B). These results may be due to the highly negative osmotic potential, leading to low water potential values, particularly in the imbibition initial phase. This reduces the water availability to the seeds (Oliveira et al. 2015), which, depending on the genotype or species, can significantly decrease the germination speed index (Andréo-Souza et al. 2010, Pereira et al. 2012).

It is important to note that high ion levels in plants can interfere in the cell membrane permeability (Greenway \& Munns 1980, Taiz et al. 2017), thus reducing the germination in high-saline substrates, with saline levels varying according to the species (Andréo-Souza et al. 2010).

During germination, both varieties exhibited salt tolerance up to certain water electrical conductivity levels, with a performance in BRS RC seeds superior to the BRS GA1. However, increased salt levels inhibited germination in both varieties. The germination results in this study corroborate those reported by Cavalcante et al. (2002) and Oliveira et al. (2015), who studied the possibility of using salt water in the production of passion fruit seedlings and observed a decreased germination with a rise in salt levels. A decline in germination indices and rates caused by salinity was also reported by Sá et al. (2016). The shoot dry weight reached a maximum of $0.110 \mathrm{~g}$ in both passion fruit varieties, with estimated water electrical conductivity of $1.96 \mathrm{dS} \mathrm{m}^{-1}$ and $3.10 \mathrm{dS} \mathrm{m}^{-1}$, respectively for BRS GA1 and BRS $\mathrm{RC}$ (Figure 1C), whereas the root dry weight was higher in the BRS GA1 (0.046 g) than for the BRS RC (0.036 g) (Figure 1D).

According to the analysis of variance summary (Table 2), regarding significant effects of the irrigation water salinity $\mathrm{x}$ variety interaction, a significant effect 
was observed for the chlorophyll content index (SPAD), maximum quantum efficiency of PSII (Fv/ Fm) and leaf dry weight. A significant effect $(p<0.05)$ was also recorded for all the growth, physiology and plant biomass variables, except for leaf area. With respect to the two passion fruit varieties, statistically significant differences $(p<0.05)$ were also observed for all the variables, except for stem and root dry weight. Similar results have been reported for the same variables, in seedlings of different crops, caused by water electrical conductivity (Sá et al. 2013, Bezerra et al. 2016, Souza et al. 2018).

The increase in water salinity prompted a $42.28 \%$ linear decline in the average plant height of
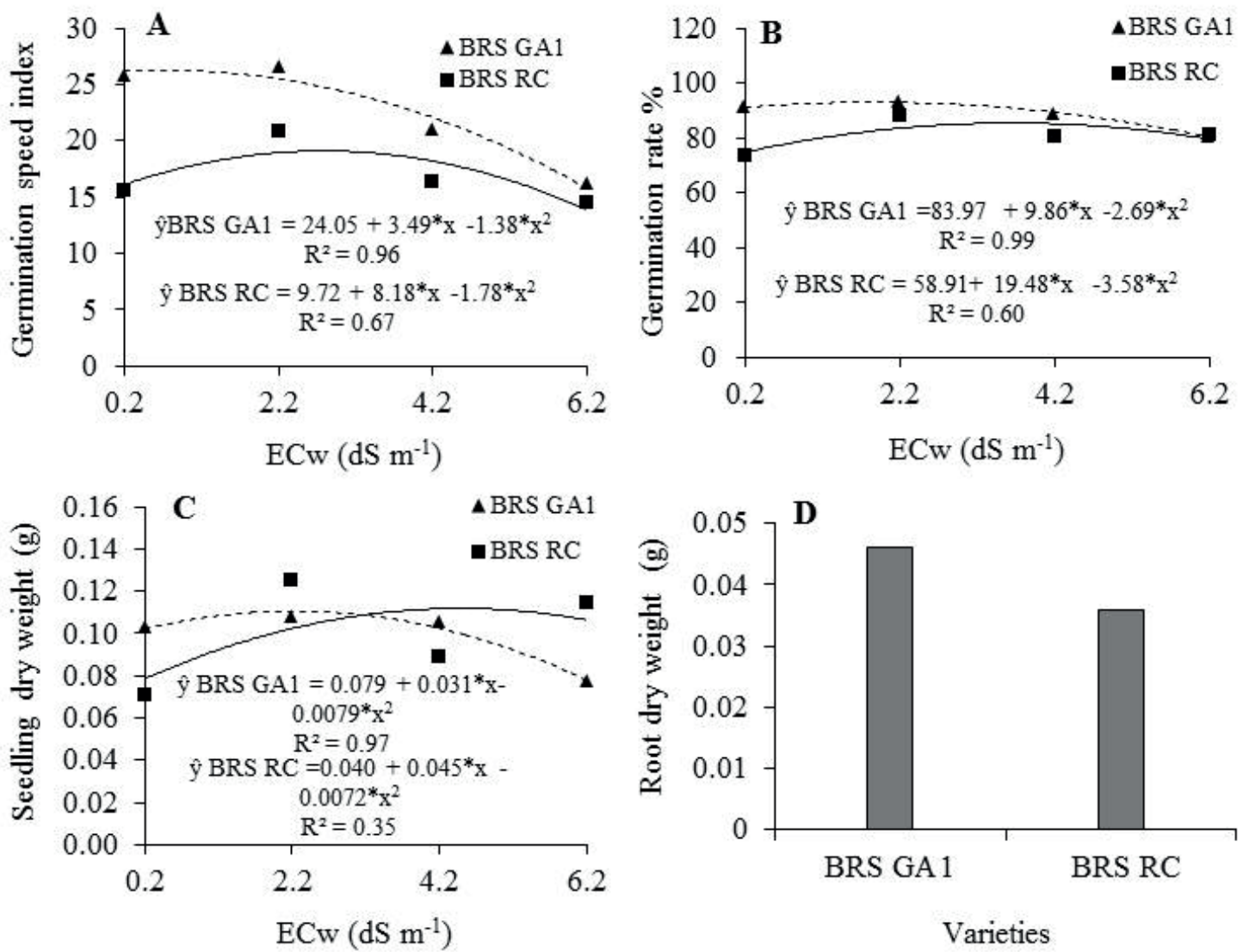

Figure 1. Effects of irrigation water electrical conductivities $(\mathrm{ECW})$ on germination speed index $(\mathrm{A})$, germination rate $(\mathrm{B})$, seedling dry weight (C) and root dry weight (D) of passion fruit varieties.

Table 2. Analysis of variance summary for plant height (PH), stem diameter (SD), number of leaves (NL), chlorophyll content index (SPAD), maximum quantum efficiency of PSII (Fv/Fm), leaf area (LA), and leaf (LDW), stem (SDW) and root (RDW) dry weight of passion fruit varieties submitted to irrigation water electrical conductivities.

\begin{tabular}{|c|c|c|c|c|c|c|c|c|c|}
\hline \multirow{2}{*}{ Sources of variation } & \multicolumn{9}{|c|}{ F-test } \\
\hline & $\mathrm{PH}$ & SD & $\mathrm{NL}$ & SPAD & $\mathrm{Fv} / \mathrm{Fm}$ & LA & LDW & SDW & RDW \\
\hline Salinity (S) & $19.05^{*}$ & $13.66^{*}$ & $12.60 *$ & $5.31 *$ & $8.49 *$ & $1.56^{\mathrm{ns}}$ & $1.06^{*}$ & $7.85^{*}$ & $5.92 *$ \\
\hline Linear regression & $56.03 *$ & $37.85^{*}$ & $36.02 *$ & $243.40 *$ & $25.32 *$ & $1.77^{\mathrm{ns}}$ & $45.19^{*}$ & $22.12 *$ & $12.07 *$ \\
\hline Quadratic regression & $1.07^{\mathrm{ns}}$ & $0.09^{\text {ns }}$ & $1.71^{\mathrm{ns}}$ & $6.20 *$ & $0.09^{\text {ns }}$ & $1.99^{\mathrm{ns}}$ & $5.70^{*}$ & $1.40^{\mathrm{ns}}$ & $0.00^{\text {ns }}$ \\
\hline Variety (V) & $9.48^{*}$ & $25.10^{*}$ & $8.67 *$ & $11.82 *$ & $17.27 *$ & $81.82 *$ & $33.39 *$ & $0.16^{\mathrm{ns}}$ & $0.20^{\text {ns }}$ \\
\hline $\mathrm{S} \times \mathrm{V}$ & $0.47^{\mathrm{ns}}$ & $1.26^{\mathrm{ns}}$ & $0.17^{\mathrm{ns}}$ & $1.18^{*}$ & $4.01 *$ & $1.78^{\mathrm{ns}}$ & $0.76^{*}$ & $0.64^{\mathrm{ns}}$ & $0.96^{\mathrm{ns}}$ \\
\hline Block & 3.34 & 0.01 & 0.30 & 43.13 & 0.00 & 89.00 & 0.13 & 0.01 & 0.01 \\
\hline Residue & 0.63 & 0.04 & 0.29 & 2.72 & 0.00 & 68.20 & 0.18 & 0.04 & 0.01 \\
\hline CV(\%) & 7.10 & 6.00 & 6.60 & 10.60 & 2.20 & 7.70 & 15.00 & 17.90 & 9.60 \\
\hline
\end{tabular}

ns, *: not significant and significant, respectively, according to the F-test at $5 \%$. 
both varieties, among seedlings irrigated with water electrical conductivity of $0.2 \mathrm{dS} \mathrm{m}^{-1}$ and $6.2 \mathrm{dS} \mathrm{m}^{-1}$ (Figure 2A). By contrast, BRS GA1 seedlings grew $14.44 \mathrm{~cm}$, surpassing the BRS RC cultivar by only $8.08 \%$, whose seedlings grew $13.36 \mathrm{~cm}$ (Figure 2B). A similar effect was observed for stem diameter, which decreased by approximately $31 \%$, in seedlings irrigated with water containing the lowest and highest salt levels (Figure 2C), with the largest stem diameter $(3.70 \mathrm{~mm})$ measured in the BRS RC and $3.33 \mathrm{~mm}$ in the BRS GA1 variety (Figure 2D). Similarly, a $32.9 \%$ decline in the number of leaves was observed with a rise in the water electrical conductivity (Figure 2E). However, the highest number of leaves was recorded for the BRS GA1 variety (Figure 2F).

Similar plant height results were reported by Bezerra et al. (2016), who studied the BRS Sol do Cerrado and Redondo Amarelo passion fruit varieties and found a $24.6 \%$ decline between the lowest and highest water electrical conductivity. Oliveira et al. (2015) analyzed the BRS GA1 variety under salt stress and also observed that higher water electrical conductivity levels reduced the plant height, stem diameter and number of leaves in seedlings by around $37.0 \%, 13.8 \%$ and $42.3 \%$, respectively. This was
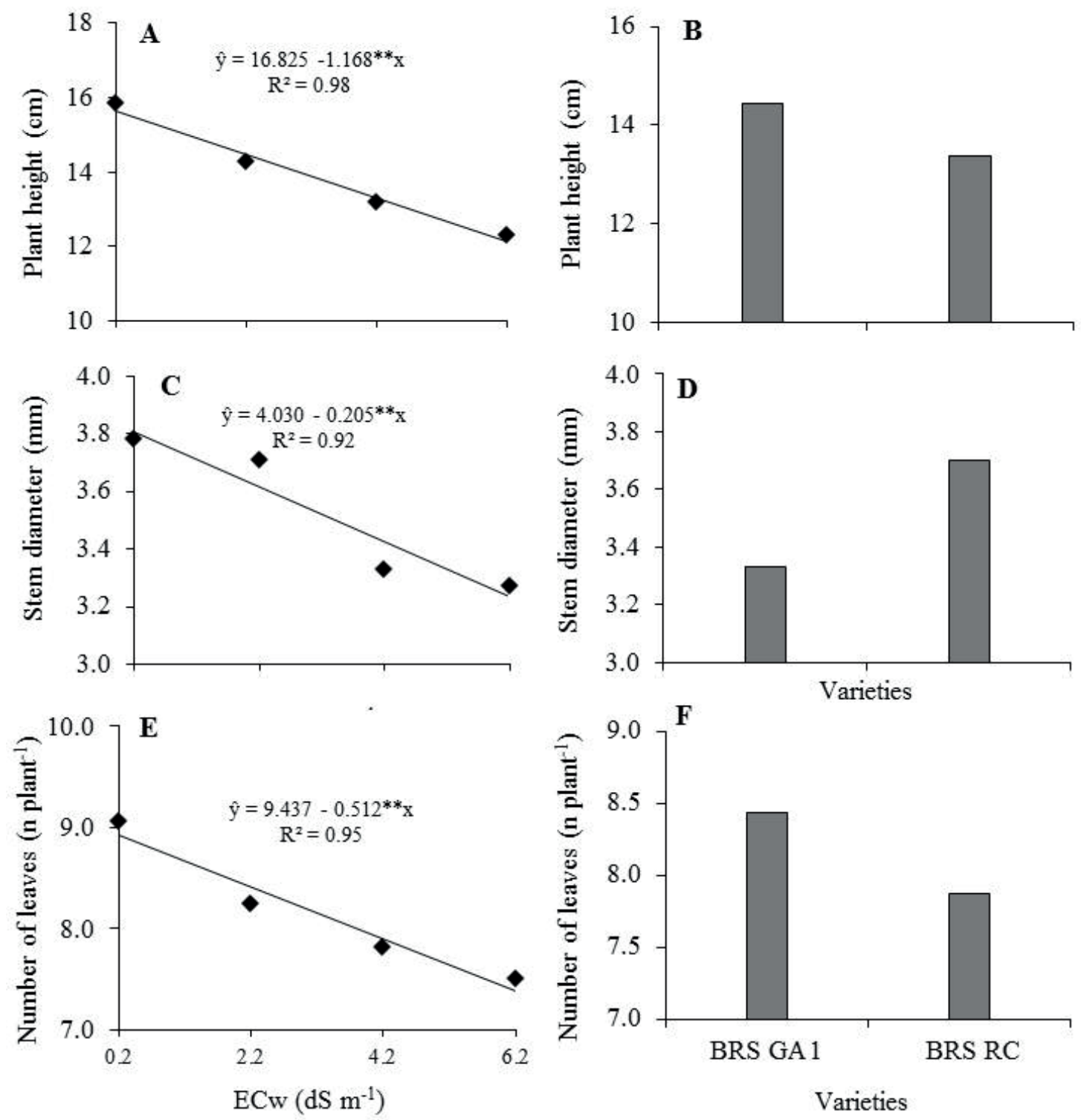

Figure 2. Plant height (A and B), stem diameter (C and D) and number of leaves (E and F) of passion fruit varieties submitted to irrigation water electrical conductivities. 
likely provoked by ion toxicity, specifically sodium and chloride, which can cause a nutrient imbalance and reduce plant growth (Sá et al. 2013, Souza et al. 2016).

The increase in water electrical conductivity resulted in a linear decline for the SPAD index in both the passion fruit varieties studied, with reductions of $44.7 \%$ and $53.2 \%$, respectively for the BRS GA1 and BRS RC (Figure 3A). The highest SPAD index was recorded for the BRS GA1, likely due to its larger leaf area, since the larger the leaf area the more pigments are present.

$\mathrm{The} \mathrm{Fv} / \mathrm{Fm}$ ratio did not vary among the water electrical conductivity values for the BRS GA1 variety, with an average of 0.76 , but decreased by around $17 \%$ in the BRS RC, with the rise in the saline levels (Figure 3B). The Fv/Fm ratio, which indicates the maximum quantum efficiency of PSII, has been widely used to identify disturbances in the photosynthetic system of plants as a result of
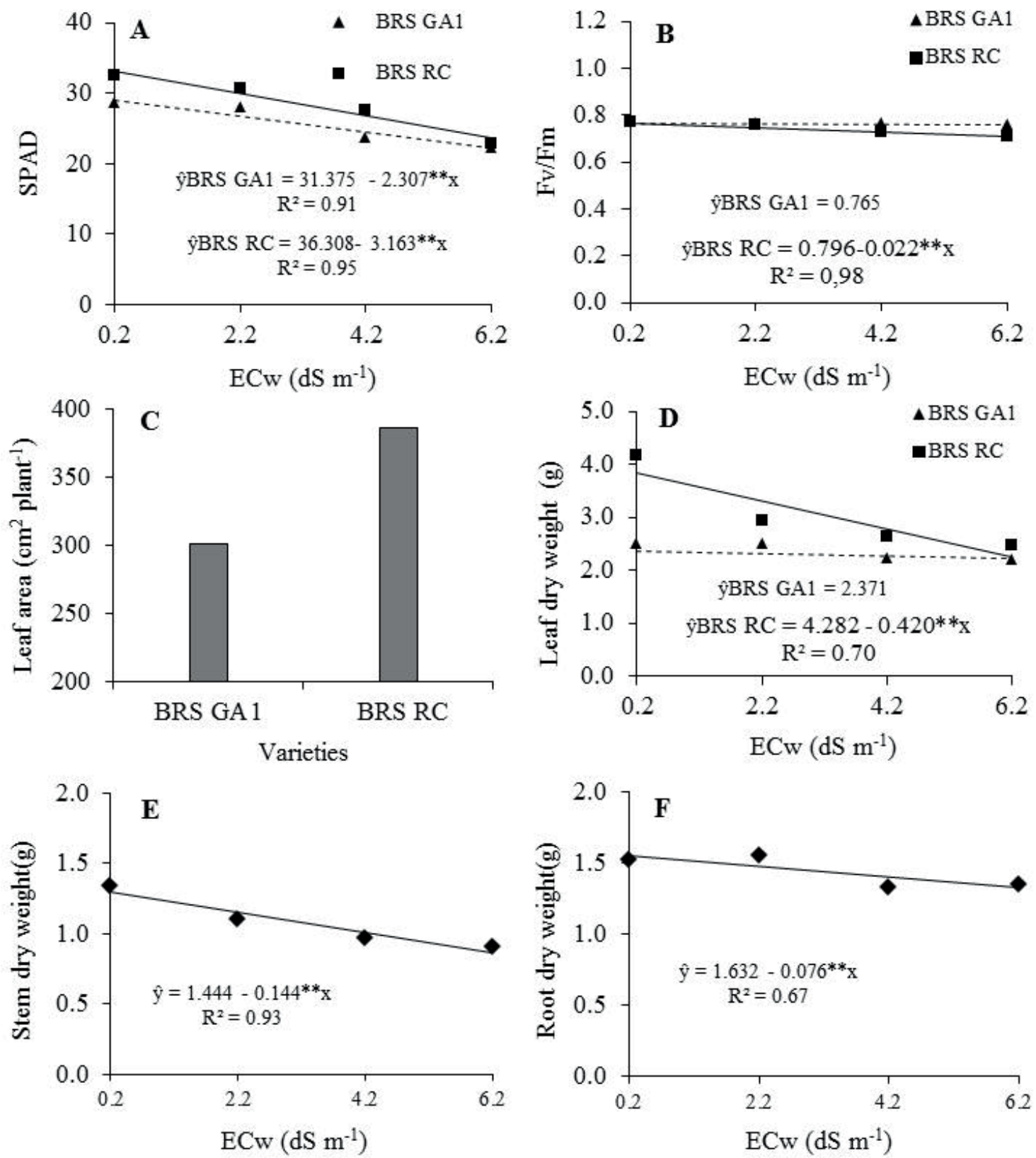

Figure 3. Chlorophyll content index (SPAD) (A), Fv/Fm (B), leaf area (C), leaf dry weight (D), stem dry weight (E) and root dry weight $(\mathrm{F})$ of passion fruit varieties submitted to irrigation water electrical conductivities. 
salt stress, since its decline reflects on damage to the photosynthetic apparatus (Maxwell \& Johnson 2000, Freire et al. 2014). According to Bjorkman \& Demming (1987), the Fv/Fm ratio is practically constant in different species, and values ranged from 0.75 to 0.86 , under conditions without stress, when the photosynthetic apparatus of the plants was intact.

The photosynthetic apparatus of the BRS RC variety was damaged by the rise in water electrical conductivity from $4.2 \mathrm{dS} \mathrm{m}^{-1}$ onwards, as reported by Freire et al. (2014) in yellow passion fruit seedlings, which exhibited a decline in the Fv/Fm ratio at $4.5 \mathrm{dS} \mathrm{m}^{-1}$. By contrast, the consistency of $\mathrm{Fv} / \mathrm{Fm}$ values in the BRS GA1 indicates that the photosynthetic apparatus of the plants was not affected by salt, resulting in higher plant height, number of leaves and leaf dry weight values.

The largest leaf area was recorded for the BRS $\mathrm{RC}$ variety $\left(386 \mathrm{~cm}^{2}\right)$ and the smallest in the BRS GA1 $\left(300.6 \mathrm{~cm}^{2}\right)$ (Figure 3C). Additionally, the leaf dry weight did not vary among the water electrical conductivity levels in the BRS GA1 variety, but fell $60 \%$ with a rise of water electrical conductivity in the BRS RC (Figure 3D). In turn, both the stem dry weight (Figure 3E) and root dry weight (Figure 3F) decreased with the increase in saline levels from $0.2 \mathrm{dS} \mathrm{m}^{-1}$ to $6.2 \mathrm{dS} \mathrm{m}^{-1}$, with reductions of $61.0 \%$ and $28.2 \%$, respectively.

According to Sá et al. (2013), the reduction of leaf area is a reflection of the reduction in leaf expansion, in order to adjust osmotically. This behavior possibly occurred in the BRS GA1 variety, since there was no change in the leaf dry mass production with the increase in the water electrical conductivity.

Salt tolerance varies substantially in seedlings, even among genotypes of a same species, as observed in the two passion fruit varieties studied here (BRS GA1 and BRS RC) and by other authors (Sá et al. 2013 and 2017, Bezerra et al. 2016, Moura et al. 2017, Souza et al. 2018) in different crops. According to Taiz \& Zeiger (2013), salt stress can cause a nutrient and physiological imbalance that directly influences the conversion of carbon assimilated by plants, promoting a reduced growth and biomass accumulation, which may vary between varieties of a same species. This was confirmed by Sá et al. (2013), who reported that cultivars commonly differ, since they have individual physiological and nutritional needs.

\section{CONCLUSIONS}

1. Salt tolerance in passion fruit seedlings varies between stages and varieties;

2. The BRS Gigante Amarelo variety exhibits higher germination indices and rates than those of the BRS Rubi do Cerrado, under saline conditions;

3. Germination is inhibited by the electrical conductivity of the irrigation water;

4. In the seedling growth stage, the photosynthetic apparatus of the BRS Gigante Amarelo remains undamaged, reflecting a greater leaf biomass.

\section{REFERENCES}

AGUIAR, R. S. et al. Produção e qualidade de frutos híbridos de maracujazeiro-amarelo no norte do Paraná. Revista Brasileira de Fruticultura, v. 37, n. 1, p. 130137, 2015.

ANDRÉO-SOUZA, Y. et al. Efeito da salinidade na germinação de sementes e no crescimento inicial de mudas-de-pinhão. Revista Brasileira de Sementes, v. 32, n. 2, p. 83-92, 2010.

BEZERRA, J. D. et al. Crescimento de dois genótipos de maracujazeiro-amarelo sob condições de salinidade. Revista Ceres, v. 63, n. 4, p. 502-508, 2016.

BJORKMAN, O.; DEMING, B. Photon yield of $\mathrm{O}_{2}$ evolution and chlorophyll fluorescence characteristics at $77 \mathrm{~K}$ among vascular plants of diverse origins. Planta, v. 170, n. 2, p. 489-504, 1987.

BRASIL. Ministério da Agricultura, Pecuária e Abastecimento. Secretaria de Defesa Agropecuária. Regras para análise de sementes. Brasília, DF: MAPA/ ACS, 2009.

CAVALCANTE, L. F. et al. Germinação de sementes e crescimento inicial de maracujazeiros irrigados com água salina em diferentes volumes de substrato. Revista Brasileira de Fruticultura, v. 24, n. 3, p. 748-751, 2002.

CAVALCANTE, P. G. S. et al. Morpho-physiological adaptation of Jatropha curcas L. to salinity stress. Australian Journal of Crop Science, v. 12, n. 4, p. 563571, 2018.

DIAS, T. J. et al. Qualidade química de frutos do maracujazeiro-amarelo em solo com biofertilizante irrigado com águas salinas. Revista Brasileira de Engenharia Agrícola e Ambiental, v. 15, n. 3, p. 229-236, 2011.

FERREIRA, D. F. Sisvar: a guide for its bootstrap procedures in multiple comparisons. Ciência e Agrotecnologia, v. 38, n. 2, p. 109-112, 2014. 
FREIRE, J. L. O. et al. Rendimento quântico e trocas gasosas em maracujazeiro amarelo sob salinidade hídrica, biofertilização e cobertura morta. Revista Ciência Agronômica, v. 45, n. 1, p. 82-91, 2014.

GORLA, C. M.; PEREZ, S. C. J. G. A. Influência de extratos aquosos de Miconia albicans Triana, Lantana camara L., Leucaena leucocephala (Lam) de Wit E Drimys winteri Forst, na germinação e crescimento inicial de sementes de tomate e pepino. Revista Brasileira de Sementes, v. 19, n. 2, p. 261-266, 1977.

GREENWAY, H.; MUNNS, R. Mechanisms of salt tolerance in nonhalophytes. Annual Review of Plant Physiology, v. 31, n. 1, p. 149-190, 1980.

INSTITUTO BRASILEIRO DE GEOGRAFIA E ESTATÍSTICA (IBGE). Banco de dados agregado. 2016. Available at: < http://www.cnpmf.embrapa.br/Base_de Dados/index_pdf/dados/brasil/maracuja/b1_maracuja. pdf $>$. Access on: 09 Jun. 2018.

LIMA, G. S. et al. Irrigação com águas salinas e aplicação de prolina foliar em cultivo de pimentão 'All Big'. Comunicata Scientiae, v. 7, n. 4, p. 513-522, 2016 b.

LIMA, I. M. O. et al. Diferentes substratos e ambientes protegidos para o crescimento de mudas de maracujazeiro amarelo doce. Revista de Agricultura Neotropical, v. 3, n. 4, p. 39-47, 2016a.

MAXWELL, C.; JOHNSON, G. M. Chlorophyll fluorescence: a practical guide. Journal of Experimental Botany, v. 51, n. 345, p. 659-668, 2000.

MOURA, R. S. et al. Formation of seedlings of species from the genus passiflora under saline stress. Bioscience Journal, v. 33, n. 5, p. 1197-1207, 2017.

NOBRE, R. G. et al. Emergência, crescimento e produção da mamoneira sob estresse salino e adubação nitrogenada. Revista Ciência Agronômica, v. 44, n. 1, p. 76-85, 2013.

OLIVEIRA, F. A. et al. Interação salinidade da água de irrigação e substratos na produção de mudas de maracujazeiro amarelo. Comunicata Scientiae, v. 6, n. 4, p. 471-478, 2015.

PEREIRA, M. R. R. et al. Influência do estresse hídrico e salino na germinação de Urochloa decumbens e Urochloa ruziziensis. Bioscience Journal, v. 28, n. 4, p. 537-545, 2012.
RICHARDS, L. A. Diagnosis and improvement of saline and alkali soils. Washington, DC: U.S. Salinity Laboratory, 1954.

SÁ, F. V. S. et al. Produção de mudas de mamoeiro irrigadas com água salina. Revista Brasileira de Engenharia Agrícola e Ambiental, v. 17, n. 10, p. 1047-1054, 2013.

SÁ, F. V. S. et al. Seed germination and vigor of different cowpea cultivars under salt stress. Comunicata Scientiae, v. 7, n. 4, p. 450-455, 2016.

SÁ, F. V. S. et al. Vigor and tolerance of cowpea (Vigna unguiculata) genotypes under salt stress. Bioscience Journal, v. 33, n. 6, p. 1488-1494, 2017.

SILVA, E. M. et al. Morfofisiologia de porta-enxerto de goiabeira irrigado com águas salinizadas sob doses de nitrogênio. Comunicata Scientiae, v. 8, n. 1, p. 32-42, 2017.

SILVA, S. L. F. et al. Influência de porta-enxertos na resistência de mudas de cajueiro ao estresse salino. Pesquisa Agropecuária Brasileira, v. 44, n. 4, p. 361367, 2009.

SOUSA, A. B. O.; BEZERRA, M. A.; FARIAS, F. C. Germinação e desenvolvimento inicial de clones de cajueiro comum sob irrigação com água salina. Revista Brasileira de Engenharia Agrícola e Ambiental, v. 15, n. 4, p. 390-394, 2011.

SOUSA, G. B. et al. Salinidade do substrato contendo biofertilizante para formação de mudas de maracujazeiro irrigado com água salina. Revista Caatinga, v. 21, n. 2, p. 172-180, 2008.

SOUZA, F. M. et al. Desenvolvimento inicial e tolerância de cultivares de maxixe irrigado com água salina. Revista Brasileira de Agricultura Irrigada, v. 12, n. 1, p. 23852394, 2018.

SOUZA, L. P. et al. Formation of 'Crioula' guava rootstock under saline water irrigation and nitrogen doses. Revista Brasileira de Engenharia Agrícola e Ambiental, v. 20, n. 8, p. 739-745, 2016.

TAIZ, L. et al. Fisiologia e desenvolvimento vegetal. 6. ed. Porto Alegre: Artmed, 2017.

TAIZ, L.; ZEIGER, E. Fisiologia vegetal. 5. ed. Porto Alegre: Artmed, 2013. 